\title{
Seasonal Variations of Some Trace Elements Concentrations of Baladi Goat Milk and their Relationship with Reproductive Characteristics Under Environmental Conditions of Aswan Governorate Damarany, A. I. \\ Department of Animal and Poultry Production, Faculty of Agriculture and Natural Resources, Aswan University, Egypt.
}

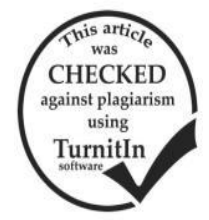

\begin{abstract}
This investigation aimed to determine the seasonal variations of zinc and copper concentrations in Egyptian Baladi goat milk, in relation to some reproductive characteristics under environmental conditions of Aswan governorate. Zinc and copper concentrations in Baladi goat's milk were determined using atomic absorption (AA) flame spectrometry techniques. The study was carried out on 32 pregnant Baladi goats that reared under the environmental conditions of Aswan governorate. According to season of kidding, goats were divided randomly into two comparable groups. Goats in the first group kidded in cool season and in the second one kidded in warm season. Results showed that higher concentrations $(\mathrm{P}<0.05)$ of zinc and copper were found in Baladi goat's milk during cool months and warm months $(0.77 \pm 0.324$ and $0.65 \pm 0.012$ vs. $0.48 \pm 0.113$ and $0.23 \pm 0.011 \mathrm{mg} / \mathrm{l})$ respectively. Kidding and twinning rates were insignificantly higher in Baladi goats kidded during the cool season (151.7 and $68.2 \%$ ) than the warm season (144.4 and 61.5\%). Rates of stillbirth, abortion and retained placenta were insignificantly higher in Baladi goats kidded during the warm season (15.4, 15.6 and 18.5\%) compared with (11.4, 9.4 and 17.2\%) in cool season, respectively. There is a positive correlation between copper concentrations in Baladi goats milk and both kidding and twining rates. Similar trend, showed between zinc concentrations and kidding rate $(r=0.589,0.577$ and 0.614$)$, respectively. There was negative correlation between zinc and copper concentrations in Baladi goat's milk and stillbirth, abortion rates. Similar trend, showed with retained placenta rate. The study observed that the seasonal changes in concentrations of zinc and copper in Baladi goat's milk related strongly with reproductive process of goats. The reproductive phenomena of Baladi goats during the cool season was better than that during the warm season. Supplementation of zinc and copper to diets of Baladi goats during the warm season improve the reproductive characteristics.
\end{abstract}

Keywords: Baladi goats, season, zinc, copper, reproductive characteristics.

\section{INTRODUCTION}

In Egypt, sheep and goats play an important role for providing economic benefits, particularly to the small framers under extensive system as in Upper Egypt. Under Upper Egypt conditions, intake of minerals depend mainly on the forages species, quantity and quality. Therefore, the imbalance in trace elements could be occurred. So, severe deficiency in trace elements can caused a serious nutritional disorder, great reduction in feed intake and conversion and reproductive complications. Combination of both shortage of feeding and severe heat stress (intensity and duration). Therefore, the animals unfurling distress, the ambient temperature reached about $45^{\circ} \mathrm{C}$ or more for several months of summer season. Egyptian Baladi goats is one of the animal breeds that reared in Upper Egypt. The goats depend on grazing of the crops residues for feeding. In the extensive system, the reproductive process of goats was affected by the mineral contents in the forages. Machado et al. (2005) and Meeske et al. (2006) reported that there was a fluctuations in mineral concentrations of clover during different seasons. Michlova et al. (2016) found that the different of the concentrations of minerals in small goat's milk related to the quality of feed and grazing, which is conjugated with variations in plants and climate. Zarazaga et al. (2004) reported that nutrition is an important factor affecting reproductive process in the farm animals. Many investigations interested with the role of trace elements in the reproduction process of goats (El-Nour et al., 2010; Habeeb et al., 2013 ; Kundu et al., 2014). It is well established that trace elements affects all the reproductive efficiency in both males and females ruminants, particularly zinc, copper and selenium. Zinc and copper influence on reproductive processes in cattle (Wilde, 2006). Abdel-Monem and El-Shahat (2011) found that supplementation of zinc to the diet of Baladi ewes improved the reproductive performance. Kundu et al. (2014) reported that supplementation of zinc to the basal diet of goats improved the reproductive parameters. Abd-El-Monem et al. (2015) reported that increasing the levels of copper in the diets tended to improve estrus response, pregnancy, lambing rates and litter size in Baladi sheep. The present investigation aimed to study the influence of seasonal variations in concentrations of trace elements ( zinc and copper ) in Baladi goat's milk reared under the environmental conditions of upper Egypt and their relationships with some reproductive characteristics.

\section{MATERIALS AND METHODS}

\section{Climate conditions and location :}

The farm of goats there is in Kom Ombou, Aswan governorate. The weather of Aswan is dry. The seasons were divided into two seasons cool season and warm season. Ambient temperature throughout the experimental period was ranged between (20 to 45 ) and ( 9 to $35^{\circ} \mathbf{C}$ ) during warm and cool season respectively. While, the relative humidity was ranged between (16 to 26 ) and ( 18 to $40 \%$ ) during warm and cool season respectively

\section{Experimental animals and management:}

Total of 32 pregnant Baladi goats ranged between 18- $25 \mathrm{~kg} \mathrm{BW}$ were used during two season and 29 goat dose kidded in the cool months and 27 goats were kidded during warm months. The age and parity of all animals ranged between 2 to 4 year and $3^{\text {rd }}$ 
to $5^{\text {th }}$,respectively. The goats reared in enclosed area. The goats were fed on some concentrate at night and grazing on residues of crops in the morning. The pasture content of residues of herbs and Alfa alfa and wheat .

Reproductive characteristics:

The reproductive characteristics were estimate as (kidding rate, stillbirth rate, abortion rate, retained placenta rate and twining rate) by Tadeg et al. (2015): Kidding rate $=$ Number of kids born/total number of goats kidded. Stillbirth rate $=$ Number of kids stillborn / total number of kids born. Abortion rate $=$ Number of goats aborted /total number of goats pregnant. Retained placenta rate $=$ Number of goats with retained placenta $(\geq 12 \mathrm{hr}) /$ number of goats kidded. Twining rate $=$ Number of twins / total number of kids born.

\section{Assessment of zinc and copper:}

The baladi goat's milk samples were collected from 29 goats that kidded during cool season and 27 goats that kidded during warm season. The samples were taken in the morning, after fourteen days postpartum. Copper and zinc were analyzed by using atomic absorption (AA) flame according to (AOAC, 2000).

Statistical analysis:

One-way analysis

The statistical model included one factor ( season of the year). T. test using SAS (2002). When the comparison between percentage, Chi Squire was performed. Pearson correlation coefficients were used. The used model was: $\mathbf{Y} \mathbf{i j}=\boldsymbol{\mu}+\mathbf{B i}+\mathbf{e i j}$ Where: Yij $==$ the observations trait, $\mu=$ overall mean $\mathrm{Bi}=$ effect of season $(\mathrm{cool}=1$, warm $=2)$ and eij $=$ experimental error

\section{RESULTS AND DISCUSSION}

\section{Zinc concentration in Baladi goat's milk:}

From table (1) the overall mean of zinc concentration of Baladi goat's milk was $1.25 \pm 0.221$ $\mathrm{m} / \mathrm{l}$. The present finding is ranged between ( 0.99 and $2.12 \mathrm{mg} / \mathrm{l}$ ) as found by Slacanac et al. (2011) and Abed Al-Helaly et al. (2013) of goat's milk. Lower concentration $0.56 \mathrm{mg} / \mathrm{l}$ of zinc in goat milk was reported by Jooyandeh et al. (2010). Meanwhile, the present value is lower than that reported by Kondyli et al. (2007), being $3.7 \mathrm{mg} / \mathrm{l}$ in goat milk. Concentration of zinc in Baladi goat's milk was higher during cool season $(0.77 \pm 0.324 \mathrm{mg} / \mathrm{l})$ than in warm season $(0.48 \pm 0.113$ $\mathrm{mg} / \mathrm{l}, P \leq 0.05$ ) (Table, 1). The present result agreed with that reported by Khan et al. (2003) and KędzierskaMatysek et al. (2013). Similar trend was reported by Bartowska et al. (2013), who reported that seasonal variations of mineral in goat's milk might be due to the changes in goats feeding during the different grazing season.

Table 1. Zinc and copper concentrations $(X \pm S E$, $\mathrm{mg} / \mathrm{l})$ in Baladi goat's milk throughout warm and cool season

\begin{tabular}{|c|c|c|}
\hline Elements & Warm season Cool season & Overall mean \\
\hline$\overline{\mathrm{Zn}}$ & $0.48 \pm 0.113^{\mathrm{a}} 0.77 \pm 0.324^{\mathrm{b}}$ & $1.25 \pm 0.221$ \\
\hline $\mathrm{Cu}$ & $0.23 \pm 0.011^{\mathrm{a}} \quad 0.65 \pm 0.021^{\mathrm{b}}$ & $0.44 \pm 0.011$ \\
\hline
\end{tabular}

\section{Copper concentration in Baladi goat's milk:}

The overall mean of copper concentration in Baladi goat's milk was $0.44 \pm 0.011 \mathrm{mg} / \mathrm{l}$ (Table, 1) Concentration of copper was similar to the result reported by El-Bagermi et al. (2014) and Michlova et al. (2016) being 0.40 and $0.53 \mathrm{mg} / \mathrm{l}$ in goat milk, respectively. Jooyandeh et al. (2010) reported lower concentration of copper in goat milk $0.05 \mathrm{mg} / \mathrm{l}$. However, higher concentration of copper in goat milk was reported by Kondyli et al. (2007) being $0.8 \mathrm{mg} / \mathrm{l}$. Concentration of copper in goat milk during the cool season was higher $(P \leq 0.05)$ than warm season (Table, 1). Similar finding were reported by Khan et al. (2003) and Kędzierska-Matysek et al. (2013). Michlova et al. (2016) reported that the variation in concentrations of goat's milk minerals might be due to feed and pasture quality, during the different grazing seasons.

Reproductive characteristics of Baladi goats during the warm and cool seasons:

Warm season showed higher values of each of stillbirth, abortion and retained placenta rates than those obtained in cool season. Meanwhile, kidding and twining rates showed the opposite trend, being higher in cool season than those during warm season (Table,2). However, all difference in these rates are insignificant $(P \leq 0.05)$.

From table (2) Kidding rate of Baladi goats was $148.1 \%$. The value is agreed with that found by AbdAllah et al. (2015), being $140 \%$ in Baladi goat that reared under environmental conditions in Egypt. The obtained result is higher than that finding by Aldomy et al. (2009) and Ince (2010), who found that the kidding rate of goats ranged between 81 and $114.5 \%$, respectively. While the rate was lower than that reported by Bouvery et al. (2003) who found that the kidding rate of goats ranged between (170- $260 \%$ ). Kidding rate of Baladi goats was higher during cool season (151.7\%) than warm season (144.4\%), however, the difference was insignificant $(\mathrm{P} \leq 0.05)$ (Table, 2). Andries et al. (2011) reported that there was variation in Kidding rate during the season being $198 \%$ in spring season and $188 \%$ in fall season.

The percentage of stillbirth $13.4 \%$ is presented in Table (2). The present result is almost equal to that obtained by Tadeg et al. (2015), being $12.8 \%$ in goats of Ethiopia. Lower value (28.57\%) was reported by AbdAllah et al. (2015) of Baladi goats in Egypt. The present result is higher than that reported by Aldomy et al. (2009) and Mude et al. (2010), who found the stillbirth percentage was 8.5 and $10 \%$ respectively. Stillbirth percentage during warm season was higher (15.4\%) than in cool season $(11.4 \%)$, however, the difference was insignificant $(\mathrm{P} \leq 0.05)$. The result is agreed with that reported by Ershaduzzaman et al. (2007) and Debele et al. (2011), who found that the stillbirth percentage was higher in hot season than cold one.

The average of abortion rate was $12.5 \%$ (Table, 2 ). Similar abortion rate reported by Aldomy et al. (2009) $(13 \%)$ of goats. Higher abortion rate in goats was reported by Mude et al. (2010) and Zahraddeen et al. (2010) 20 and 26\%, respectively. Abortion rate during the warm season was higher $(15.6 \%)$ than that during 
the cool season $(9.4 \%)$, however, the difference was insignificant $(\mathrm{P} \leq 0.05)$. Similar trend, reported by Mahmud et al. (2014), who reported that abortion rate was lower in cold season than in hot season in goats.

Rate of retained placenta was $17.9 \%$ table ( 2 ). The obtained result agrees with that reported by Mahmud et al. (2014),16.9\%. Lower rate of retained placenta reported by Tadeg et al. (2015) and Alenyorege and Mensah (2015) 7.4 and 11\%, respectively. But, the present rate of retained placenta was lower than that found by Zahraddeen et al. (2010) in goats $34.0 \%$. Incidence of retained placenta during warm season was higher 18.5 than in cool season (17.2\%), however, the difference was insignificant $(\mathrm{P} \leq$ $0.05)$. Similar trend was reported by Mahmud et al. (2014).

Twining rate in Baladi goats was $65.1 \%$ table (2). Moaeen-ud-Din et al. (2008) and Aldomy et al. (2009) reported lower rate in goats, 24.9 and $45.4 \%$, respectively. Twining rate of Baladi goats in cool season was higher $68.2 \%$ than in warm season $61.5 \%$, however the difference was insignificant $(\mathrm{P} \leq 0.05)$. This result is in agreement with that reported by Webb and Mamabolo (2004), reported that twining rate in goats was lower in hot season than in cold season.

Table 2. Percentages of some reproductive characteristics of Baladi goats throughout warm and cool seasons

\begin{tabular}{lccc}
\hline Rates & Warm season Cool season & Overall \\
\hline \multirow{2}{*}{ Kidding } & 144.4 & 151.7 & 148.1 \\
& $39 / 27$ & $44 / 29$ & $83 / 56$ \\
Stillbirth & 15.4 & 11.4 & 13.4 \\
& $6 / 39$ & $5 / 44$ & $11 / 83$ \\
Abortion & 15.6 & 9.4 & 12.5 \\
& $5 / 32$ & $3 / 32$ & $8 / 64$ \\
Retained placenta & 18.5 & 17.2 & 17.9 \\
& $5 / 27$ & $5 / 29$ & $10 / 56$ \\
Twining & 61.5 & 68.2 & 65.1 \\
& $24 / 39$ & $30 / 44$ & $54 / 83$ \\
\hline
\end{tabular}

The correlation between zinc concentrations in Baladi goat's milk and reproductive characteristics:

There is a positive correlation $(\mathrm{P} \leq 0.05)$ between

each of kidding and twinning rate and zinc concentrations was showed in Baladi goat's milk table ( 3 ). While, negative correlation was recorded between each of stillbirth and abortion and zinc concentrations in Baladi goat milk. Similar trend, was observed of retained placenta and concentration of zinc in baladi goat milk (Table, 3). The obtained correlation is in agreement with that reported by Kędzierska-Matysek et al. (2013), who found positive correlation between zinc in goat milk and reproductive process. Vázquez-Armijo et al. (2011) reported that zinc is directly affect on reproductive process of goats by expression of estrus, embryo implantation and reduction in spermatogenesis. Also, O'Donoghue and Boland (2002) found that lower zinc concentration was related to increase abnormal estrus and abortion rate in cows. Aliyu et al. (2015) reported positive correlation between zinc and amino acids in goat milk.
Table 3. Correlation coefficients between zinc and copper concentration in Baladi goat's milk and reproductive characteristics.

\begin{tabular}{lccccc}
\multicolumn{6}{c}{ and reproductive characteristics. } \\
\hline \multirow{6}{*}{ Elements } & Reproductive characteristics rates (\%) \\
& Kidding & Stillbirth & Abortion & $\begin{array}{c}\text { Retained } \\
\text { placenta }\end{array}$ & Twining \\
\hline $\mathrm{Zn}$ & $0.614^{*}$ & $-0.884^{*}$ & $-0.768^{*}$ & $-0.595^{*}$ & 0.461 \\
& & & & & \\
$\mathrm{Cu}$ & $0.589^{*}$ & $-0.693^{*}$ & $-0.707^{*}$ & $-0.825^{*}$ & $0.577^{*}$
\end{tabular}

$\overline{a, b}$ : values within the same row with different superscripts are significantly different at $5 \%$ level.

The correlation between copper concentration in Baladi goat's milk and reproductive characteristics There is a positive correlation $(\mathrm{P} \leq 0.05)$ between each of kidding and twinning rate and copper concentration in Baladi goat's milk was observed table(3). However, the correlation between each stillbirth, abortion and retained placenta and copper concentration in baladi goat milk was negative table(3). The present result agreed with that found by Kędzierska-Matysek et al. (2013), who reported a positive correlation between copper in milk and reproductive process in goats. Blache et al. (2008) reported that nutritional status considered one of the important factors effect on reproductive process in goats. Sales et al. (2011) reported that copper play an important role in regulating progesterone production by luteal cells via involvement of superoxide dismutase in crossbred heifers. Positive correlation between copper and amino acids in goat's milk was reported by Aliyu et al. (2015).

\section{CONCLUSION}

The present investigation display that seasonal fluctuation of zinc and copper concentrations in Baladi goat's milk was related obviously with variations in the reproductive process of goats, like improve the reproductive phenomena of goats during the cool season than in warm season. Supplementation of zinc and copper to diets of Baladi goats during warm season are highly beneficial as proved by improving the reproductive characteristics under environmental condition of Aswan governorate.

\section{REFERENCES}

Abd-Allah. S; R. Salama; M. I. Mohamed; M. M. Mabrouk; R. I. EL-Kady; A. I. Kadry and S. M. Ahmed (2015). A comparative study on reproductive and productive performance of Boer and Baladi goats raised under similar environmental conditions in Egypt. Inter. J. Chem Tech. Res., 8 (9): 225-236.

Abed Al-Helaly, L.; S. H. Rashed and L. F. Bdaiwi (2013). A comparative study of oxidant and antioxidant levels between human milk with other types of ruminant animals. Iraqi Nat. J. Chem., 49: 86-99. 
Abdel- Monem, U. M. and K. H. EL-Shahat (2011). Effect of different dietary levels of inorganic zinc oxide on ovarian activities, reproductive performance of Egyptian Baladi ewes and growth of their lambs. Bulgarian J. Vet. Med., 14 ( 2): 116-123.

Abdel-Monem, U. M.; S.A. Peris and A. I. A. El-Shorbagy (2015). Effect of copper sulphate supplementation on semen quality, ovarian activities and reproductive performance of Egyptian Baladi sheep. J. Am. Sci., 11(10): 42- 50.

Aldomy, F.; N. O. Hussein; L. Sawalha, K. Khatabeh and A. Aldomy (2009). A national survey of prenatal mortality in sheep and goats in Jordan. Pakistan Vet. J., 29(3): 102-106.

Alenyerege, B. and K. Mensah (2015). Incidence of retained placenta in ruminants and its treatment by rural farmers in northern Ghana. Indian $\mathrm{J}$. Appl. Res., 5 (7):434- 438.

Aliyu, A. O.; M. D. Faruruwa and A. H. Abdu (2015). Seasonal evaluation of mineral elements, heavy metals, essential amino acids, proximate compositions and pesticides in goat milk. World J. Analy. Chem.,3 (1): 1-9.

Andries, K. M. (2011). Effects of season of kidding on doe performance in commercial Boer cross does. Sheep \& Goat Res. J., 26:20-26.

AOAC (2000). Official Methods of Analysis. 17th Edition. Gaithersburg, Maryland, USA.

Bartowska J.; A. Wolanciuk; M. Kędzierska-Matysek and Z. Litwinczuk ( 2013). Effect of production season on the basic chemical composition and content of macro- and microelements in cow and goat milk. Zywn. Nauk. Technol. Jak., 6 (91): 69-78.

Blache, D.; S. K Maloney and D. K. Revell (2008). Use and limitations of alternative feed resources to sustain and improve reproductive performance in sheep and goats. Anim. Feed Sci. Tech., 147:140-157.

Bouvery, N. A.; A. Souriau, P. Lechopier and A. Rodolakis (2003). Experimental coxiella burnetii infection in pregnant goats: excretion routes. Vet. Res., 34 : 423-433.

El-Bagermi, M. A.; H. G. M. Edwards and A. I. Alajtal (2014). A comparative study on the physicochemical parameters and trace elements in raw milk samples collected from MisurataLibya. SOP Trans. Analy. Chem., 1 (2):15-23.

Debele, G; M. Duguma and F. Hundessa ( 2011). Effect of different factors on mortality rate of Arsi- Bale kids in Mid Rift Valley of Ethiopia. Glob. Vet., 6 (1): 56-60.

El-Nour, H. M.M ; H. M. A. Abdel- Rahman and S. A. El-Wakeel (2010). Effect of zinc-metallothionein supplementation on reproductive performance , kids performance, minerals profile and milk quality in early lactating Baladi goats. World Appl. Sci. J., 9 (3): 275- 282.

Ershaduzzaman, M.; M. M. Rahman, B. K. Roy and S. A. Chowdhury (2007). Studies on the diseases and mortality pattern of goats under farm conditions and some factors affecting mortality and survival rates in Black Bengal kids . Bangl. J. Vet. Med., 5 (1 \& 2): 71-76.
Habeeb, A. A. M.; A. A. EL-Tarabany and A. E. Gad (2013). Effect of zinc levels in diet of goats on reproductive efficiency, hormonal levels, milk yield and growth aspects of their kids. Glob. Vet., 10 (5): 556-564.

Ince, D. (2010). Reproductive performance of Saanen goats raised under extensive conditions. Afr. J. Bio., 9 (48):8253-8256.

Jooyandeh, H. and A. Aberoumand (2010). Physicochemical, nutritional, heat treatment effects and dairy products aspects of goat and sheep milks. World Appl. Sci. J., 11 (11): 1316-1322.

Kędzierska-Matysek, M.; J. Bartowska; Z. Litwinczuk and N. Koperska (2013). Content of macro and microelements in goat milk in relation to the lactation stage and region of production. J. Elem. Sci., 107-114.

Khan, Z. I.; M. Ashraf; M. Y. Ashraf; Z. Rahman and A. Hussain (2003). Mineral status of livestock (Goats and Sheep) based on soil , dietary components and animal tissue fluids in relation to seasonal changes and sampling period in specific region of Pakistan. J. Anim. Vet. Adv., 2: (8): 478- 495.

Kondyli E.; M. C. Katsiari and L. P. Voutsinas (2007). Variations of vitamin and mineral contents in raw goat milk of the indigenous Greek breed during lactation. Food Chem., 100 (1): 226-30.

Kundu, M. S.; A. Kumar De; S. Jeyakumar; J. Sunder; A. Kundu and T. Sujatha (2014). Effect of zinc supplementation on reproductive performance of Teressa goat. Vet. World, 7 (6):380-383.

Mahmud, M. K.; M. Atiqkur Rahman; A. Al-Maruf; A. M.. Sayam; M. A. Mutaleb; M. I. Ali and M. A. Habib (2014). Prevalence of reproductive diseases and disorders in cows and goats recorded in two veterinary hospitals in Bangladesh. Am. Res. Thou., 1 (1): 285-303.

Meeske, R.; A. Rothauge; G. D. Van der Merwe and J. F. Greyling (2006). The effect of concentrate supplementation on the productivity of grazing Jersey cows on a pasture based system. South Afric. J. Anim. Sci., 36: 105-110.

Michlova,T.; A. Hejtmankova; H. Dragounova and S. Hornickova (2016). The content of minerals in milk of small ruminants. Agro. Res., 14: 1407-1418.

Moaeen-ud-Din, M.; L. G. Yang; S. L. Chen; Z. R. Zhang; J. Z. Xiao; Q. Y. Wen and M. Dai (2008). Reproductive performance of Matou goat under sub-tropical Monsoonal climate of Central China. Trop. Anim. Health, Prod., 40:17-23.

Mude, S. W.; S. P. Waghmare; S. G. Mode; P. G. Sukare and S. A. Adlak (2010). Effect of mineral supplementation on post-parturient diseases in pregnant goats. Vet. World, 3: 109- 110.

O'Donoghue, D.G. and M. Boland (2002). The effect of proteinated trace minerals on fertility and somatic cell counts of dairy cattle. J. Dairy Sci., 78: 248-255.

Sales, J.N.S.; R.V.V. Pereira; R.C. Bicalho and P.S. Baruselli (2011). Effect of injectable copper, selenium, zinc and manganese on the pregnancy rate of crossbred heifers (Bos indicus $\times$ Bos taurus) synchronized for timed embryo transfer. Live. Sci., 142(1-3): 59-62. 
SAS (2002). User's Guide: Statistics, Version 9.0 Edition. SAS Institute Inc., Cary, NC, USA

Slacanac, V.; J. Hardi; M. Lucan; D. K. Komlenic; V. Krstanovic and M. Jukic (2011). Concentration of nutritional important minerals in Croatian goat and cow milk and some dairy products made of these. Croat. J. Food Sci. Tech., 3 (1): 21-25.

Tadeg, W. M.; F. R. Gudeta; T. Y. Mekonen; Y. T. Asfaw; A. L. Birru and A. A. Reda (2015). SeroPrevalence of small ruminant brucellosis and its effect on reproduction at Tellalak district of Afar region, Ethiopia. J Vet. Med. Anim. Health, 7(4):111-116.

Vázquez-Armijo, J. F.; R. Rojo; D. López; J. L. Tinoco; A. González; N. Pescador and I. A. Domínguez-Vara (2011). Trace elements in sheep and goats reproduction: A review. Trop. Sub. Agro., 14: 1 - 13
Webb, E. C. and M. J. Mamabolo (2004). Production and reproduction characteristics of south African indigenous goats in communal farming systems. South Afric.. J. Anim. Sci., 34: 236- 239.

Wilde, D. (2006). Influence of macro and micro minerals in the peri-parturient period on fertility in dairy cattle. Anim. Rep. Sci., 96:240-249.

Zahraddeen, D.; I. S. R. Butswat and L.S. Taimako (2010). Assessment of reproductive problems in some ruminants under small holder husbandry system in Bauchi, Nigeria. J. Vet. Sci., 4: $1-8$.

Zarazaga, L. A.; J. L. Guzman; C. Dominguez; M.C. Perez and R. Prieto (2004). Effect of plane of nutrition on seasonality of reproduction in Spanish Payoya goats. Anim. Reprod. Sci., 87: 253-267.

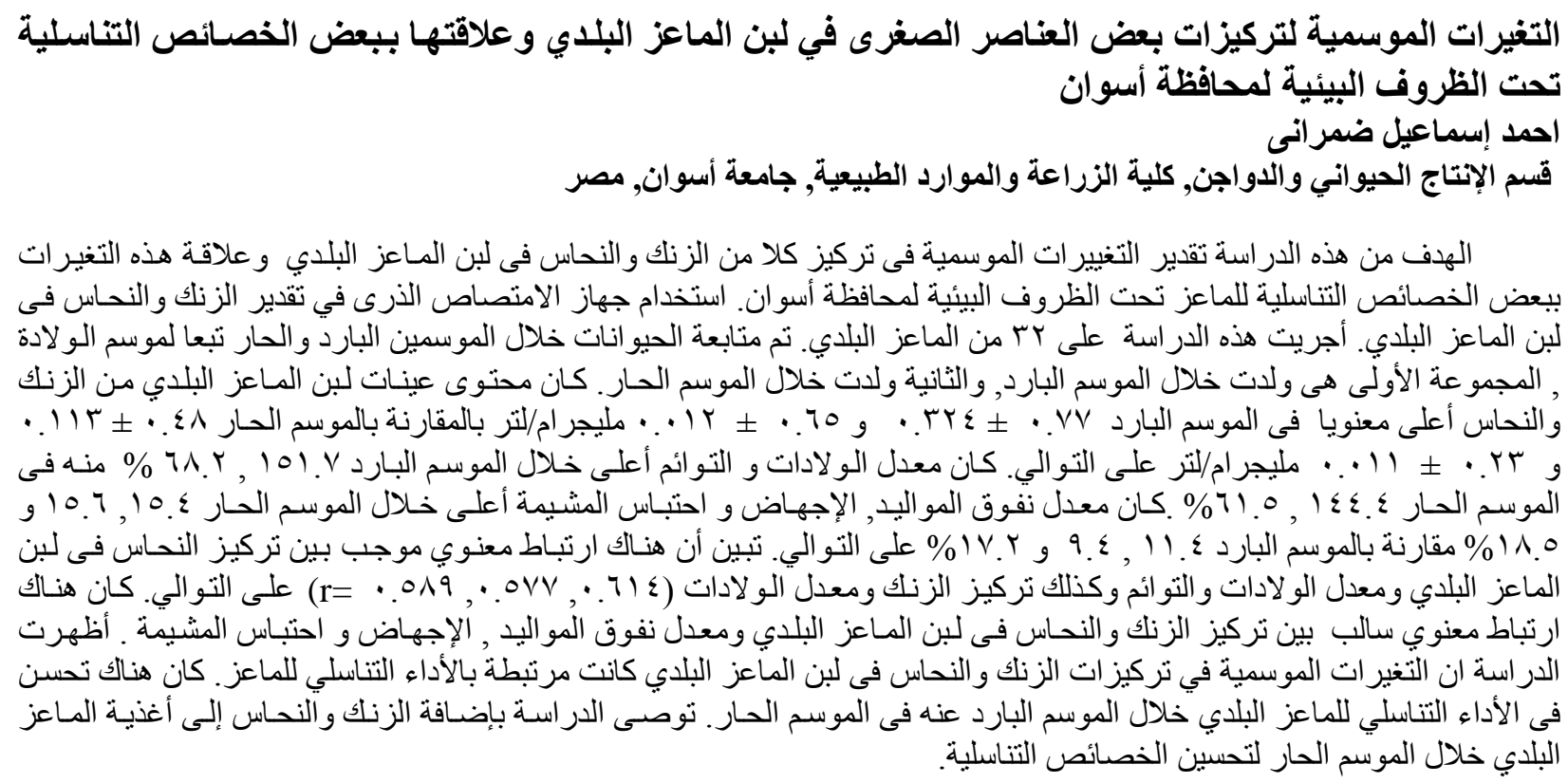

